\title{
Service Quality and Consumer Choice of Their Preferred Telecommunications Service Provider in Ghana
}

\author{
Afako Jephthah Kwame, Afako Jeremiah Kwaku, and Tian Hongyun
}

\begin{abstract}
This study examines the effect of service quality on customer choice. Specifically, it investigated the relationship between service quality dimensions and customer choice, examining the effect of service quality dimensions on customer choice and the service quality dimension most preferred by customers. The quantitative research approach was used with a sample of 250 respondents using purposive and convenient sampling technique. Questionnaires were used to collect the data and analyzed using SPSS version 21 . With regards to the correlation variables, it showed a strong positive relationship between service quality dimensions and customer choice of a mobile network service provider and the regression variables showed a significant effect between service quality and customer choice indicating that service quality is very important and influence customers' choice in choosing a mobile network service provider. It was recommended that Mobile network service providers should continue to improve on the service quality dimensions (empathy, responsiveness, reliability assurance, and tangibility). Since customers look out for these dimensions when choosing a mobile network service provider.
\end{abstract}

Index Terms - Service Quality, Consumer Choice, Telecommunication, Ghana.

\section{INTRODUCTION}

Ghana's telecommunication industry is characterized by stiff competition with five international mobile network companies, namely; MTN, Vodafone, Glo mobile, Airtel Tigo, and Expresso, (National Communications Authority, 2013). This vibrant competition in the market/industry triggered Mobile Network Service Providers to embark on various advertising and modification, as well as introducing new services to maintain existing customers and attracting new ones, (Iddrisu, 2011).

The mobile network service providers are willing and ready to attend to the needs of subscribers anywhere at any time. As a result of this, service quality has become a priority in the undertakings of each mobile network service provider in order to go ahead of their competitor. Maintaining existing and attracting new customers is key to them, (Vijay \& Krishnaveni, 2016). For instance, in the third quarter of 2017, MTN had the largest market share of $46.58 \%$ followed by Vodafone with $24.25 \%$. Tigo also had $14.66 \%$, and Airtel with $11.36 \%$, Glo had $2.09 \%$ and Expresso $0.06 \%$. However, the recent merger of Airtel and Tigo will place Airtel-Tigo as

Published on November 19, 2019

Afako Jephthah Kwame is with the School of Management, Jiangsu University, 301, Xuefu Rd. Zhenjiang, P.R. China

(e-mail: afako.jeph@gmail.com ).

Afako Jeremiah Kwaku is with Distant Learning College, University of Education, Winneba, P. O. Box 25, Winneba, Ghana. the second largest with approximately $26.02 \%$ of the market share in the telecommunication industry (NCA 2017). This spelled out clearly the performance of the respective Telecommunication service providers in Ghana, and their exuberance in providing quality services to meet and exceed customer's expectation.

Service quality has been labeled by many writers, including krey et al, (2014), as addressing the needs and desires of customers, coupled with delivery provisions to meet customers' expectations. Service quality has also been described by Lovelock (2000), as the excellence level expectation and control over the level of excellence to meet customer interests. In a broader perspective implies that a service will merit the status of being quality when it is able to meet and exceed customers' aspirations. Service quality plays a vital role in the mobile telecommunication industry, (Kollman 2000), as it forms the basis of attracting customers to patronize a particular brand.

However, Olatokum \& Nwonne, (2012) affirmed that service quality has an impact on consumer's purchasing behaviour and decision. This implies that the choice of a consumer is dependent on how quality a service is. Therefore, optimum customer satisfaction, impelled by quality services, should be the key goal of service providers. (Panda, 2003; Iddrisu 2011).

Consumer choice is the behaviour consumers' display in their quest to purchase, use, evaluate, and dispose of products, services, and ideas, (Schiffman \& Kanuk, 1997). They further explained that consumer behaviour is, therefore, the study of how individuals make decisions to spend their available resources on the consumption-related items. This implies that consumer behaviour encompasses what, why, when, where and how often consumers purchase and use the purchased products. Most of these consumers purchasing decision are often attracted by influences or factors beyond their compromise. Some of these influences or factors may emerge from their background, family, social status, among others. This has inspired the researchers to conduct a study by assessing the effect of service quality on consumers' choice of mobile network service providers.

\section{Problem Statement}

Despite the rising competition in Ghana's Telecommunication market and the rising customer base,

(e-mail: afakojeremiah@gmail.com )

Tain Hongyun is with the School of Management, Jiangsu University, 301, Xuefu Rd. Zhenjiang, P.R. China

(e-mail: twfh7522@163.com ) 
customers are still caught up in their persistent complaints about the service quality of these Telecommunication network providers in the country, (Iddrisu, 2011). In this case, the quality of service customers receive is not the one that meets their satisfaction. Thus, service quality is most likely to be one of the topmost priorities when it comes to choosing a network service provider. Customers' dissatisfaction with service quality was highlighted by the introduction of the Mobile Number Portability in 2011 in the country. Within 25 days of its introduction, 21,000 mobile phone subscribers ported their numbers. Thus, switching from one operator to another (NCA, 2011). This occurrence displayed how consumers were not content with the service they receive from their mobile network service providers.

Several researchers and writers have attested to the reason that, service quality can influence customer's choice of service provider (Waruter, 2015). Loke et al (2011) also revealed that there is a relationship between service quality and customer satisfaction. However, the success of a mobile network service provider depends if not entirely but to an extent on how quality a customer considers the services of the mobile service provider to be. This study, therefore, seeks to investigate and establish a paradigm shift from service quality on customers' loyalty and satisfaction to the effect of service quality on customer choice of Telecommunication Network Provider.

\section{Research Objectives}

The general objective of the study was to investigate or examine the effects of service quality on customers' choice of service provider.

\section{Specific Objectives;}

i. To determine the relationship between the service quality dimensions and customer choice.

ii. To examine the effect of service quality dimensions on customers' choice of mobile service provider.

iii. To examine the effect of service quality on customer choice of a mobile network service provider.

\section{LITERATURE REVIEW}

\section{A. Theories/Concepts Underpinning the study}

There are several theories and models that could be related to the manner and the way consumers behaved/ made their choices based on how quality the services of a company are. These choices are often attributed to the patronage of a particular good or service. For the purposes of this study, the researchers decided to concentrate on the Marshallian economic model and the SERVQUAL Model

\section{B. The Marshallian economic model}

The Marshallian economic model posits that a buyer expends his or her income on goods and services that bring the most satisfaction taking into consideration his/her preference and relative prices (Pachauri, 2002). This model is a build up from the works of both Adam Smith and Jeremy Benthan. Thus, the underlying idea of this model existed in the works of early economists like Adam Smith and Jeremy Benthan. Smith in his doctrine of economic growth argued that self-interest is the impetus for all the actions a man takes. Benthan, on the other hand, refined this view holding that man mostly calculates and weights carefully, the expected pains and pleasures of every single action he ponders(Pieter,2002).

By the time, Bentham's theory was applied to consumer behaviour late in the 19th century; the "marginal-utility" theory of value was formulated independently and almost simultaneously by Walras in Switzerland, Menger in Australia and Jevons and Marshall in England (Kotler \& Gould; 1979).

The theoretical work of Alfred Marshall, who was the consolidator of the classical and neo-classical tradition in economics aimed at realism, is founded in his method to examine the effect of change in a single variable, for example, price, when all other variables were held constant, based on simplified assumptions. In the quest for greater realism, Marshall "reasoned out" consequences of the provisional assumptions and modified his assumptions in subsequent steps. Marshall's methods and assumptions have been refined to the Modern Utility Theory, where the economic man maximizes his utility and does this by carefully calculating the "felicific" consequences of any purchase. Runyon \& Stewart (1987: 695) add to the discussion by stating that Marshall used money as the common denominator of psychological needs, where the value of satisfying a specific need could be equated and compared with other needs in terms of cost.

\section{Application of the theory}

The above theory depicts that consumers only made choices based on how rewarding those choices were going to be to them. Thus, consumers purchase decisions will most times based on how satisfying those services were going to be to them. A consumer's patronage of a mobile service had a lot to do with how those services were going to meet and exceed their expectations. However, the extent of quality of the services of a mobile network can meet or not meet the customer's expectation, taking other factors into consideration. Some of these influencing factors can be the family background, social media, social status, friends and many more. These consumer behavioral factors can influence a consumer to patronize the services of a Mobile Service Provider, regardless of the extent of quality of that particular service.

\section{SERVQUAL Model}

Service quality is an approach to manage business processes in order to ensure full satisfaction of the customers \& quality in service provided. It works as an antecedent of the customer satisfaction. Its expectation is great than that of performance, then perceived quality is less than satisfactory, hence customer dissatisfaction occurs. SERVQUAL is a service quality framework, developed in the eighties by Parasuraman, Zeithanl \& Berry (1988), and aimed at measuring the level of quality in the service industry. The instrument will form the basis for the measurement of service quality in this study. The instrument comprises of five dimensions of quality namely, Tangibles, Empathy, Reliability, Assurance, and Responsiveness. The framework is showed in the figure below. 


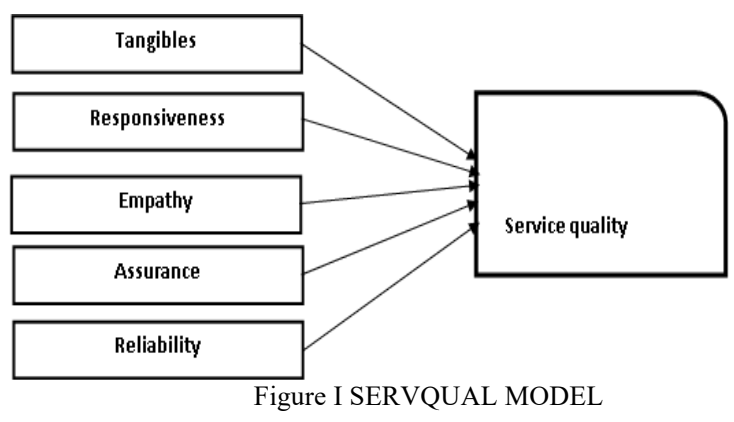

Source: Parasuraman, Zeithanl \& Berry (1988)

\section{Definitions of Terms}

Service Quality

Service quality has been defined as excellence level expectation and control over the level of excellence to meet customer interests, (Wyckoff in Lovelock, 2000). In other words, there are two main factors affecting service quality. These two factors are expected service and perceived service, (Parasuraman et al, 1991). Services quality definition is mostly centered on addressing the needs and desires of customers, and meeting and exceeding customer's expectations. If the services received/perceived service is suitable with expectation, perceived service quality and satisfaction are good. If services received exceed customer expectations, then the service quality is perceived as ideal quality. Equally, if the services received are lower than expected, then the perceived service quality is poor.

Interest and attention to service quality were first introduced by Grönroos (2000) in Tjiptono (2005), through the concept of perceived service quality and service quality model. The current study seeks to focus on service quality and its effect on customers' choice of sample mobile networks in Ghana.

\section{Reliability}

Reliability has to do with a service provider's ability to deliver promises on time (Loke et al 2011). According to Iddrisu (2011), reliability as a service quality dimension measures the consistency of performance and dependability of a service.

\section{Tangibility}

Tangibility refers to the physical facilities of the service provider, personnel and tools use to provide the service (Zeithamal et al, 2006). That is the evidence of the facilities, tools and personnel used by the service provider while offering a service.

Assurance

This refers to the ability of the workers of the service provider to communicate trust to customers and their level of courtesy. Assurance includes the knowledge and courtesy of the workers and their ability to communicate trust and confidence, (Iddrisu, 2011).

\section{Responsiveness}

Responsiveness has to do with how promptly and accurately customers' complaints and requests are dealt with or addressed. That is the readiness of the service provider to assist customers.

\section{Empathy}

Empathy as a dimension of service quality has to do with the importance and care a service provider gives to an individual customer and how well the customers' needs and preferences can be understood and attended to.

\section{E. Empirical Literature review}

Warutere (2015) in his study indicated that customers' choice of a mobile network is influenced by factors such as price, service quality and promotional activities carried out by mobile network service providers. The study revealed that mobile network service providers could attract and maintain customers' base on how quality their services are. Service quality variables, like tangibility, responsiveness, reliability, assurance, and empathy had positive influences on customer loyalty. Thus, customers' decision to stay with a network service provider or to switch to another service provider (Iddrisu, 2011).

Also, a study by Arokiasamy \& Abdullah (2013) revealed that service quality attributes have a positive and significant effect on customers' perception of service quality in the Malaysia telecommunication industry. However, customers compare prices of network service providers when purchasing the product of a particular service provider. For this reason, customers are likely to be attracted toward highquality service at a reasonable price as affirmed by Bhandari \& Kaur (2013).

Krey et al, (2014) conducted a study and it was observed that the relationship between service quality and customer loyalty in a bank may not have a direct effect on these two variables. This means that higher service quality provided by the Bank may not necessarily lead to customer loyalty and higher customer loyalty. Based on the conclusions of this study, it was recommended that service quality need special attention regarding customer's confidence, especially in providing services, in order to increase customer loyalty so that customers do not move to other banks.

\section{$F$. Conceptual framework of the study}

The conceptual framework illustrated below pinpoints the respective variables and identifiers that seek to determine the effect of service quality on Consumers' choice of mobile network service providers in Ghana. The framework depicted the relationship between service quality and consumers' choice of mobile network in the study area aforementioned above.

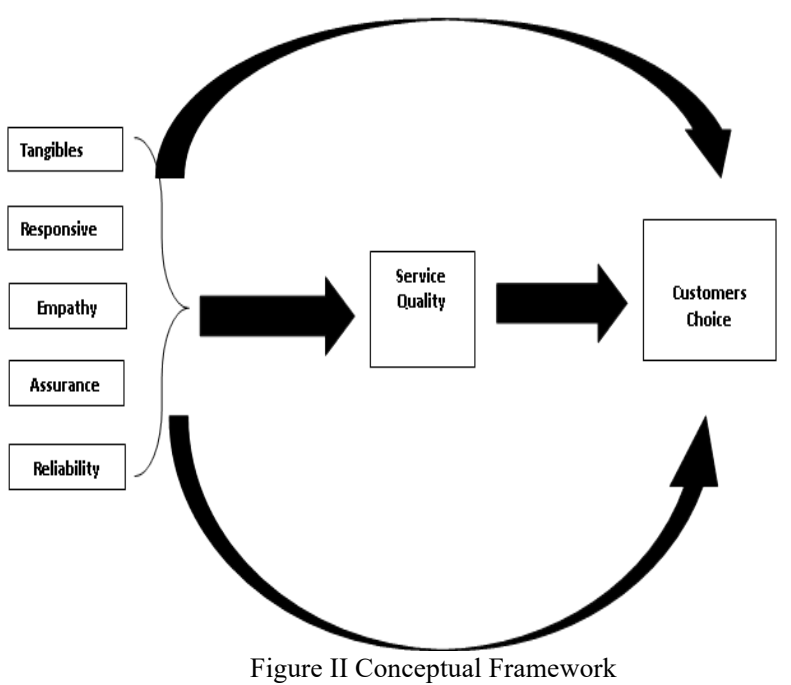

Figure II Conceptual Framework 


\section{METHODOLOGY}

\section{A. Research Design and Target Population}

The research design for this study was descriptive in nature however, it focused on a quantitative approach. This approach is relevant for testing the objectives and theories by examining the relationship between the variables. These variables were measured using scales and further analyzed using statistical procedures. The study also employed primary data in other to come up with the best conclusion that will befit the study. Questionnaires were used to gather the relevant primary data for the study.

The population of the research comprised of users of all the Mobile Network Service Providers in the country. However, customers of the Mobile Service Providers in Accra Ghana were the target of this study. Specifically, customers who are much more familiar with the activities of these mobile service providers.

\section{B. Sample Size and Sampling Procedure}

The sample size of this study was 250 customers of the various mobile Network Service providers' operation in the country. Based on how large subscribers of these network providers are, purposive and convenience sampling technique will be adopted to select the respondents in and around Accra.

\section{Data source and collection}

Data were collected from primary source for this study. The primary data was gathered by means of questionnaire administration. The primary data was gathered by means of an adapted questionnaire developed by Abdul Majeed Iddrisu (2011).

\section{Data Analysis}

Data collected from the respondents were coded, analyzed and presented by the use of application software known as the Statistical Package for the Social Sciences (SPSS) version

Pearson Correlation was also used to establish and explain the relationship between service quality dimensions and customer choice. multiple linear regression was used to determine whether service quality dimensions has an effect on customers' choice, simple linear regression was used to determine whether service quality has an effect on customer choice.

The most commonly used indicator of internal consistency, Cronbach's alpha coefficient was employed to check the reliability of the scales used for this survey. Scholars like Pallant (2003) and Hair (2010) argued that ideally, this value should be greater than 0.7 for managerial decisions although a threshold level of 0.6 could be used in exploratory research. To increase the validity and reliability of the data collected using questionnaires, the researcher based the questions solely on the objectives of the research.

\section{Reliability of Variables}

Reliability refers to the degree to which the scale or survey gives consistent output when surveying similar population. The reliability of customer choice and service

Quality (tangibility, assurance, empathy, reliability, and responsiveness) were analyzed using Cronbach's coefficient alpha in the tables shown below. Variables that have Cronbach's coefficient alpha above 0.6 were accepted as suggested by Hair et al, (2010), who argued that ideally, this value should be greater than 0.7 for managerial decisions although a threshold level of 0.6 could be used in exploratory research.

Table I Reliability of Variables

\begin{tabular}{lll} 
& $\begin{array}{l}\text { Cronbach's } \\
\text { Alpha }\end{array}$ & No. of Items \\
\hline Customer choice & 0.828 & 4 \\
Tangibility & 0.833 & 3 \\
Assurance & 0.790 & 3 \\
Empathy & 0.791 & 3 \\
Reliability & 0.765 & 3 \\
Responsiveness & 0.836 & 3
\end{tabular}

Table II Reliability Statistics of overall Variables

$\begin{array}{ll}\text { Cronbach's Alpha } & \text { No. of Items } \\ 0.948 & 20\end{array}$

Both tables assessed the reliability of the scales used for customer choice and service quality. All the variables were found to be reliable with Cronbach's Alpha value of 0.948 .

\section{RESEARCH FINDINGS AND Discussions}

\section{A. Demographic Information of the Respondents}

This study examined the demographic information of customers of mobile network service providers. The research team concentrated on customers using the five mobile network service providers in Ghana. The demographic information discussed gender, age of respondents, educational qualification, occupation and mobile network service provider they are affiliated to in tables 1 to 5 . The data was gathered from Section A of the questionnaire.

Table III Gender of Respondents

\begin{tabular}{lcccc} 
Response & Frequency & Percent & $\begin{array}{l}\text { Valid } \\
\text { Percent }\end{array}$ & $\begin{array}{l}\text { Cumulative } \\
\text { Percent }\end{array}$ \\
\hline Male & 138 & 52.0 & 52.0 & 52.0 \\
Female & 112 & 48.0 & 48.0 & 100.0 \\
Total & 250 & 100 & 100 &
\end{tabular}

The results from the table indicate that $52.0 \%$ of the respondents were males and $48.0 \%$ were females. 
Table IV Occupation of Respondents

\begin{tabular}{lccl} 
Response & Frequency & $\begin{array}{l}\text { Valid } \\
\text { Percent }\end{array}$ & $\begin{array}{l}\text { Cumulative } \\
\text { Percent }\end{array}$ \\
\hline Student & 97 & 38.0 & 38.0 \\
Public Sector & 87 & 31.3 & 69.3 \\
Private Sector & 24 & 9.3 & 78.7 \\
Self-employed & 34 & 16.0 & 94.7 \\
Unemployed & 8 & 5.3 & 100.00 \\
Total & 250 & 100.0 &
\end{tabular}

The table also shows $16 \%$ of the respondents were selfemployed. The results also showed that $9.3 \%$ were from the private sector and 5.3\% were unemployed.

Table V: Mobile Network Service Provider Respondents are affiliated to in Ghana

\begin{tabular}{llll} 
Response & Frequency & Valid Percent & $\begin{array}{l}\text { Cumulative } \\
\text { Percent }\end{array}$ \\
\hline MTN & 99 & 48.0 & 48.0 \\
Vodafone & 69 & 33.3 & 81.3 \\
Airtel/Tigo & 47 & 15.3 & 96.7 \\
Glo & & & \\
Expresso & 8 & 2.7 & 99.3 \\
Total & 250 & & \\
& & & \\
\end{tabular}

The results affirm the fair representation of the customer base of the mobile network service providers in Ghana. MTN has the largest share of $46.58 \%$ of the market, while Vodafone had $24.25 \%$ followed by Tigo with $14.66 \%$ and Airtel had $11.36 \%$ whiles glow and Expresso had a market share of $2.09 \%$ and $0.06 \%$ respectively according to NCA (2017).

\section{B. Descriptive Statistics (Mean Rating \& Standard Deviation) Of Service Quality Dimensions}

Descriptive statistics were carried out on the various variables used. Mean and Standard deviation was used to present the findings. This indicates the level to which the respondents disagreed, remained neutral or agreed with the statements in the questionnaire. The following mean ranges were used to interpret the findings in table 6 to table 10 below; (Mean: 1.00 $-2.49)=$ Disagree, $($ Mean: $2.50-3.49)=$ Neutral, $($ Mean: $3.50-5.00)=$ Agree .
Table VI: Mean Rating and Standard Deviation of Service Quality Dimension.

\begin{tabular}{|c|c|c|c|c|}
\hline Scale & $\mathrm{N}$ & Mean & $\begin{array}{l}\text { Std. } \\
\text { Deviation }\end{array}$ & Rank \\
\hline Empathy1 & 250 & 3.40 & 1.24 & \\
\hline Empathy 2 & 250 & 3.47 & 1.01 & $1^{\text {st }}$ \\
\hline Empathy 3 & 250 & 3.26 & 1.49 & \\
\hline Total mean & 250 & 3.38 & & \\
\hline Responsiveness 1 & 250 & 3.07 & 1.23 & \\
\hline Responsiveness 2 & 250 & 3.28 & 1.30 & $2^{\text {nd }}$ \\
\hline Responsiveness 3 & 250 & 3.54 & 1.36 & \\
\hline Total mean & 250 & 3.30 & & \\
\hline Reliability 1 & 250 & 3.56 & 1.27 & \\
\hline Reliability 2 & 250 & 3.13 & 1.25 & $3^{\text {rd }}$ \\
\hline Reliability 3 & 250 & 3.05 & 1.23 & \\
\hline Total mean & 250 & 3.25 & & \\
\hline Assurance 1 & 250 & 2.92 & 1.35 & \\
\hline Assurance 2 & 250 & 3.11 & 1.19 & $4^{\text {th }}$ \\
\hline Assurance 3 & 250 & 3.15 & 1.27 & \\
\hline Total mean & 250 & 3.06 & & \\
\hline Tangibility 1 & 250 & 2.69 & 1.39 & \\
\hline Tangibility 2 & 250 & 3.05 & 1.34 & $5^{\text {th }}$ \\
\hline Tangibility 3 & 250 & 3.04 & 0.20 & \\
\hline Total mean & 250 & 2.9 & & \\
\hline
\end{tabular}

Scale $1=$ Strongly disagree, $2=$ Disagree, $3=$ Neutral, $4=$ Agree, 5= Strongly agree

From table 6, the result of descriptive statistics of the overall responses from the $250(\mathrm{~N})$ respondents showed that tangibility as a service quality dimension reached a total mean of 2.90. This indicates that respondents perceived a relatively medium level of tangibility aspect of service quality.

Among the service quality dimensions, empathy scored the highest mean of 3.38. The second highest dimension of service quality was responsiveness, with a mean of (3.30). The third dimension was reliability with a mean of 3.25 and assurance being fourth with a mean of 3.06. The mean of responses to empathy $(m=3.38)$ indicates that customers' choices are influenced by the level of empathy a mobile network service provider offers. 
Table VII: Mean Rating and Std. Deviation of Customer Choice

\begin{tabular}{|c|c|c|c|}
\hline Scale & $\mathrm{N}$ & Mean & Std. Deviation \\
\hline $\begin{array}{l}\text { How confidently customer personal } \\
\text { details are kept influence my choice }\end{array}$ & 250 & 3.3667 & 1.2063 \\
\hline $\begin{array}{l}\text { The attention given by employees } \\
\text { when presented with grievances } \\
\text { from customers made me chose my } \\
\text { mobile service provider. }\end{array}$ & 250 & 3.2600 & 1.2554 \\
\hline $\begin{array}{l}\text { The facilities and products of my } \\
\text { mobile service provider made me } \\
\text { like it }\end{array}$ & 250 & 3.0667 & 1.246 \\
\hline $\begin{array}{l}\text { The general service quality offered } \\
\text { by my mobile service provider } \\
\text { influenced my choice }\end{array}$ & 250 & 2.9800 & 1.2503 \\
\hline tal & 250 & 3.17 & \\
\hline
\end{tabular}

Scale $1=$ Strongly disagree, $2=$ Disagree, $3=$ Neutral, $4=$ Agree, 5= Strongly agree

From table 7, the result of descriptive statistics of customer choice of mobile service provider showed that overall customer choice reached (mean=3.17). This showed that customers were neutral about the questions asked as to what influences their choices of a mobile network service provider.

Among the customer choice statements, "how confidently customers' personal details are kept influence my choice" scored the highest mean (3.37). The second highest customer choice was "the attention given by employees when presented with grievances from customer made me choose my mobile service provider", with a mean of (3.26). The mean of responses to the overall customer choice statements $(\mathrm{m}=3.17)$ indicates the respondents perceived a relatively medium level regarding all the statements of customer choice.

\section{Correlation Matrix}

The correlation outputs were computed in order to establish a preliminary evidence of the relationship between the variables. The results of Pearson's correlation showed that all the variables are positively correlated at $1 \%$ level of significance.

\section{Table VIII: Correlation of Variables}

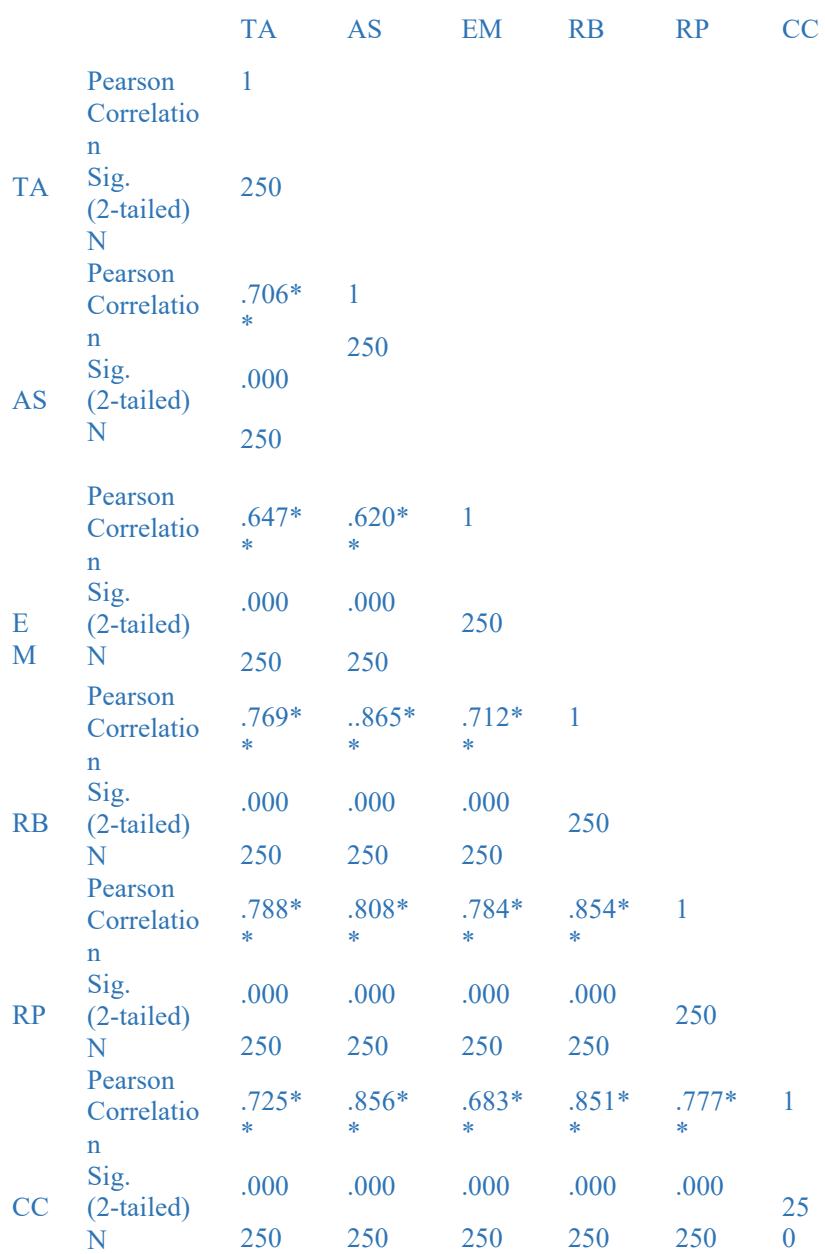

** Correlation is significant at the 0.01 level (2-tailed).

From the correlation table 10 above, a strong positive relationship exists between the service quality dimensions and customer choice. Assurance and reliability had the highest correlation of $(\mathrm{r}=0.865, \mathrm{p}<0.01)$. This means there is a very strong relationship between assurance and reliability followed by Assurance and customer choice $(\mathrm{r}=0.856$, $\mathrm{p}<0.01)$ indicating that customers make choice and take decisions based on trust and delivery of services on time from the mobile network service providers.

Also, there is a strong relationship between responsiveness and reliability $(\mathrm{r}=0.854, \mathrm{p}<0.01)$. This means that the more promptly customers' complaints are addressed the more likely customers will depend on a service provider. The least alpha coefficient was between empathy and assurance $(\mathrm{r}=0.620, \mathrm{p}<0.01)$.

In all, there is a strong positive relationship existing among the service quality dimensions and customer choice of a mobile network service provider. An enhancement or otherwise in any of the service quality dimensions can influence customers' choice of a mobile network service provider. Iddrisu (2011) in a similar study found out that service quality dimensions had a relationship with customer loyalty which is the choice to stay with a particular mobile network service provider or switch to another. 


\section{Analysis of Variance}

The table indicate that there is a significant effect of service quality dimensions as independent variables on customers' choice as the dependent variable. This is indicated by an Fstatistics of 113.541 ( $\operatorname{sig} 0.0000$ ). This shows that the model is a good fit which can be used for future predictions.

Table IX ANOVA

$\begin{array}{lllllll}\text { Model } & & \begin{array}{l}\text { Sum of } \\ \text { Squares }\end{array} & \text { df } & \begin{array}{l}\text { Mean } \\ \text { Squares }\end{array} & \text { F } & \text { Sig. } \\ & \text { Regression } & 1926.365 & 5 & 385.273 & 113.541 & .000^{\mathrm{b}} \\ 1 & \text { Residual } & 488.628 & 144 & 3.393 & & \\ & \text { Total } & 2414.993 & 149 & & & \end{array}$

a. Dependent Variable: Customer Choice

b. Predictors: (Constant), Responsiveness, Empathy, Tangibility, Assurance, Reliability

\section{E. Model Analysis}

The $\mathrm{R}$ value of .893 indicates that there is a strong positive and significant relationship between the service quality dimensions and customer choice. The R-square value of .798 also shows that the model explains approximately $79.8 \%$ of the variables explaining the customer choice with an adjusted $\mathrm{R}$-square value of $79.1 \%$.

\begin{tabular}{|c|c|c|c|c|}
\hline \multirow[b]{2}{*}{ Model } & \multicolumn{3}{|c|}{ Table X Model Summary } & \\
\hline & $\mathrm{R}$ & R Square & $\begin{array}{l}\text { Adjusted R } \\
\text { Square }\end{array}$ & $\begin{array}{l}\text { Std. Error of the } \\
\text { Estimate }\end{array}$ \\
\hline & $.893^{\mathrm{a}}$ & .798 & .791 & 1.84208 \\
\hline
\end{tabular}

a. Predictors: (Constant), Responsiveness, Empathy, Tangibility, Assurance, Reliability

\section{F. Analysis of Coefficient}

From the analysis in table, all things being equal, a unit change in tangibility will affect customers' choice by 0.146 . Also, a unit change in the level of assurance given by mobile network service providers will result in a 0.602 increase in the choices customers make. Furthermore, a unit change in empathy level of mobile network service providers will result in 0.206 change in the choices customers make. A unit change in the level of reliability and responsiveness of a mobile network service provider will raise customers' choice by 0.411 and reduce customers' choice by 0.120 respectively. This showed that all service quality dimensions were found to have a direct effect on customer choice of a mobile network service provider which contradicts the work of Iddrisu (2011) where only one service quality dimension(reliability) was found to have a direct effect on the choices customers make, thus the choice to be loyal or disloyal.
Table VI Coefficient Analysis

\begin{tabular}{|c|c|c|c|c|c|}
\hline \multirow[t]{2}{*}{ Model } & \multicolumn{2}{|c|}{$\begin{array}{l}\text { Unstandardized } \\
\text { Coefficients }\end{array}$} & \multicolumn{3}{|l|}{$\begin{array}{l}\text { Standardized } \\
\text { Coefficients }\end{array}$} \\
\hline & B & $\begin{array}{l}\text { Std. } \\
\text { Error }\end{array}$ & Beta & $\mathrm{t}$ & Sig. \\
\hline (Constant) & .867 & .548 & .118 & 1.582 . & .116 \\
\hline Tangibility & .146 & .079 & .479 & 1.846 & .067 \\
\hline Assurance & .602 & .098 & .163 & 6.118 & .000 \\
\hline Empathy & .206 & .078 & .316 & 2.643 & .009 \\
\hline Reliability & .411 & .119 & -.101 & 3.453 & .001 \\
\hline Responsiveness & -.120 & .108 & & $\begin{array}{l}- \\
1.113\end{array}$ & .267 \\
\hline
\end{tabular}

\section{Summary, CONClusion And ReCOMMENDATION}

\section{A. Summary of Findings}

The study purposed to find the effect of service quality on customer choice of mobile network service provider. Specifically, the study determined the relationship between service quality dimensions (tangibility, assurance, empathy, reliability, and responsiveness) and customer choice of mobile network service providers and it also determined to find the effect of service quality dimensions on customer choice of mobile network service providers.

To achieve the purpose of the study, the researchers adapted a conceptual model from Ananta Raj A. Arokiasamy and Abdul Ghani kanesan bin Abdullah, (2013) to measure the independent and dependent variables. Structured questionnaires adapted from Abdul Majeed Iddrisu (2011) was used to gather data for the study with a quantitative approach.

Overall, 250 respondents. Pearson Correlation was used to find the relationship among the variables (service quality dimensions and customer choice), multiple Linear regression was used to examine the effect of service quality dimensions on customer choice.

Regarding the correlation of the variables, a significant relationship existed between service quality dimensions and customer choice indicating that the more service quality dimensions are improved the more likely customers will choose these services of a mobile network service provider over another. This is in line with a similar study by Abdul Majeed Iddrisu (2011) where service quality dimensions were found to have a relationship with customer loyalty which is the choice to stay with a particular mobile network service provider or switch to another.

Also, in this study, all service quality dimensions were found to have a direct effect on customer choice of a mobile network service provider which contradicts the work of Iddrisu (2011) where only one service quality dimension(reliability) was found to have a direct effect on the 
choices customers make, thus the choice to be loyal or disloyal.

This study also found a strong effect of service quality on customer choice. This reinforced previous studies by Olatokun \& Nwonne (2012), where service quality was found to be the most important factor that affects customers' perception in selecting a mobile network service provider. Yirenkyi Kofi Ampomah (2012) also reveal that service quality is an important factor that customers look out for when choosing a mobile network service provider.

\section{B. Conclusion}

Based on the results from the study it is concluded that there is a strong relationship between service quality dimensions and customer choice. It is also concluded that service quality dimensions have an effect on the choices customers make with regards to which mobile network service provider to choose over the other.

The research concluded based on the findings of the study that, empathy is the service quality dimension most preferred by customers when choosing a mobile network service provider. Responsiveness was the second most preferred service quality dimension followed by reliability. Assurance and Tangibility were the least preferred service quality dimensions by customers.

As a whole, service quality was found to have a positive influence on customer choice of a mobile network service provider. It is therefore important for mobile network service providers to improve the general quality of the services while focusing on the empathy, responsiveness, and reliability of those services.

\section{Recommendations}

Based on the findings of the study, the following recommendations are made:

- Mobile network service providers should continue to improve on the service quality dimensions (empathy, responsiveness, reliability assurance, and tangibility), since customers look out for these dimensions when choosing a mobile network service provider.

- Management of the mobile network service providers should make service quality a priority when making decisions at all levels, this will help meet the quality expectations of existing and potential customers. Management should also put in place a customer friendly mechanism to receive customers' views on the quality of their services provided.

- The management of mobile network service providers should invest on network service extension as well as product and service outlets infrastructure within Accra Ghana.

- The ministry of communications should make sure mobile network service providers in the country meet quality expectations of their customers.

Because the final formatting of your paper is limited in scale, you need to position figures and tables at the top and bottom of each column. Large figures and tables may span both columns. Place figure captions below the figures; place table titles above the tables. If your figure has two parts, include the labels "(a)" and "(b)" as part of the artwork.

\section{Limitations of the study}

Although, the research findings provide some new insights to researchers, these findings should be viewed in light of the limitations

- The study only covered a few segments of the entire population due to time factor, as the researchers have to work within deadlines to meet the submission of the work and also the funds were not enough to reach out to all customers of mobile network service providers in Ghana.

- Getting people to answer the questionnaires was also a major challenge, because some of the customers were not ready to answer the questionnaires due to their busy schedule.

In light of all these limitations, the findings of this study would be of great importance to mobile network service providers, regulators, and stakeholders

\section{REFERENCES}

Arokiasamy, A. R., \& Abdullah, A. G. (2013). Service quality and customer satisfaction in the cellular telecommunication servie provider in Malaysia. Researchers World. 4(2), 1.

Creswell, J. W. (2014). A concise introduction to mixed methods research. Sage Publications.

Hair Jr, J. F., \& Lukas, B. (2014). Marketing research (Vol. 2). McGrawHill Education, Australia.

Iddrisu, A. M. (2011). Service quality and customer loyalty: The case of the Mobile Telecommunication industry in Ghana (Doctoral dissertation).

Jamal, A., \& Goode M., M. (2001). Consumers and brands: A study of the impact of self image congruence on brand preference and satisfaction " Marketing Intelligence and planning". 19(7(2001)), 482-492.

Kothari, C. R. (2004). Research methodology: Methods and techniques. New Age International.

Lovelock, C., \& Gummesson, E. (2004). Whither services marketing? in the search of a new paradigm and fresh perpectives. journal of service research, 7(1), 20-41.

Mostert, P. G. (2002). Buying behaviour of South African internet users.

Olatokun, W. (2012). Determinants of users' choice of mobile service providers in the Nigerian Telecommunication market.

Pachauri, M. (2002). Researching online consumer behaviour: current positions and future perspectives. Journal of Customer Behaviour, 1(2), 269-300.

Panda, T. K. (2002). Creating customer life time value through effective CRM in financial ervice industry. Journal of services Research, 2(2), 157.

Parasuman, A., Berry, L., \& Zeithaml, V. A. (1991). Understanding customer expectation of service. MIT sloan management review, $32(3), 39$.

Parasuraman, A., Zeithaml, V. A., \& Berry, L. (1988). Servqual; a multiple item scale for measuring consumer perc. Journal of retailing, 64(1), 12.

Paulrajan, R., \& Rajkumar, H. (2011). Service quality and customers preference of cellular mobile service providers. Journal of technology management \& innovation, 6(1), 38-45.

Raman, S., Haque, A., \& Ahmad, M. (2010). Exploring and influencing factors for the selection of mobile phone service providers: A structured equational modeling (SEM) approach on Malaysian Consumers. African Journal of Business Management, 4(13(2010)), 2885.

Saunders, M., Lewis, R., \& Thorhull, A. (2000). Research Methods for Businness Students (Second edition ed.). Essex: Pearson Education Limited.

Taiwo, A., Loke, P., Salim, H., \& Downe, A. (2011). Service Quality and Customer Satisfaction in a Telecomm Service Provider. Journal of International Conference of Financial Management and Economics, 11, 123-128.

Tjiptono, F., \& Chandra, G. (n.d.). Service, quality and satisfaction.

Vijay, P., \& Krishnaveni, V. (n.d.). Customer Preferences towards the mobile network service provider- A study with the special 
reference to coimbatore City. International Journal of

Management Research and Reviews, 6(10), 1386.

Warutere, M. (2015). Influence of price, product quality, brand image and promotion activities on choice of mobile phone network; a case of Embu town, Kenya. European Journal of business and management, 7(36).

Yirenkyi, K. A. (2012). Factors affecting customer satisfaction and preference in the telecommunications industry: a case study of MTN Ghana(Doctoral dissertation). 